\title{
Determination of Colistin B in Chicken Muscle and Egg Using Ultra-High-Performance Liquid Chromatography-Tandem Mass Spectrometry
}

\author{
Harsh Kumar ${ }^{1} \mathbb{D}_{\text {, Dinesh Kumar }}^{1, *(\mathbb{D})}$, Eugenie Nepovimova ${ }^{2}$, Dasharath Oulkar ${ }^{3}$, Anil Kumar ${ }^{1} \mathbb{D}_{\text {, }}$ \\ Ramiz Mohammad Rafi Azad ${ }^{3}$, Subodh Kumar Budakoti ${ }^{3}$, Navneet Kumar Upadhyay ${ }^{4}$, , Rachna Verma $^{5}(\mathbb{D}$ \\ and Kamil Kuča ${ }^{2, *(D)}$
}

check for updates

Citation: Kumar, H.; Kumar, D.; Nepovimova, E.; Oulkar, D.; Kumar, A.; Azad, R.M.R.; Budakoti, S.K.; Upadhyay, N.K.; Verma, R.; Kuča, K. Determination of Colistin B in Chicken Muscle and Egg Using Ultra-High-Performance Liquid Chromatography-Tandem Mass Spectrometry. Int. J. Environ. Res. Public Health 2021, 18, 2651. https:// doi.org/10.3390/ijerph18052651

Academic Editors:

Vincenzo Ferrantelli, Carlos

M. Franco, Nicola Cicero,

Andrea Pulvirenti and

Andrea Pulvirenti

Received: 24 January 2021

Accepted: 1 March 2021

Published: 6 March 2021

Publisher's Note: MDPI stays neutral with regard to jurisdictional claims in published maps and institutional affiliations.

Copyright: (c) 2021 by the authors. Licensee MDPI, Basel, Switzerland This article is an open access article distributed under the terms and conditions of the Creative Commons Attribution (CC BY) license (https:/ / creativecommons.org/licenses/by/ $4.0 /)$.
1 School of Bioengineering \& Food Technology, Shoolini University of Biotechnology and Management Sciences, Solan 173229, India; microharshs@gmail.com (H.K.); kumaranil@shooliniuniversity.com (A.K.)

2 Department of Chemistry, Faculty of Science, University of Hradec Kralove, 50003 Hradec Kralove, Czech Republic; eugenie.nepovimova@uhk.cz

3 Food Safety Solution Center, FSSAI-Thermo Fisher Scientific, Indirapuram, Ghaziabad 201014, India; dasharath.oulkar@thermofisher.com (D.O.); ramiz.azad@thermofisher.com (R.M.R.A.); subodh.budakoti@thermofisher.com (S.K.B.)

4 School of Pharmaceutical Sciences, Shoolini University of Biotechnology and Management Sciences, Solan 173229, India; navneetqa@gmail.com

5 School of Biological and Environmental Sciences, Shoolini University of Biotechnology and Management Sciences, Solan 173229, India; rachnaverma@shooliniuniversity.com

* Correspondence: dineshkumar@shooliniuniversity.com (D.K.); kamil.kuca@uhk.cz or kamil.kuca@fnhk.cz (K.K.); Tel.: +420-603-289-166 (K.K.)

\begin{abstract}
Colistin, an imperative member of the polymyxin group, is a cationic peptide antibiotic. Itis also known as polymyxin E, but this peptide antibiotic has been forbidden for human consumption due to its high toxicity. Regrettably, this antibiotic is utilized as a feed additive and veterinary drug for animals. Due to the toxicity of colistin, the presence of its residue in the animal system represents a threat to human health regarding the consumption of meat, especially chicken. A novel method was proposed for quantifying colistin B in chicken muscles and eggs using ultra-high-performance liquid chromatography-tandem mass spectrometry (UHPLC-MS/MS). In this method, extraction of colistin B from samples was achieved by mixing the sample with acidified methanol:water (1/1, $v / v)$, followed by centrifugation and filtration by a membrane filter excluding solid-phase extraction (SPE) clean up, as well as evaporation steps. The analysis was conducted by optimized liquid chromatography-tandem mass spectrometry (LC-MS/MS), and method performance was assessed in terms of the limit of quantitation, specificity, selectivity, precision, linearity and recovery in coherence with the guidelines of SANTE and the Commission Decision 2002/657/EC. The result obtained from the study showed the limit of quantitation (LOQ) as $10 \mu \mathrm{g} \mathrm{Kg}^{-1}$ for muscles and $5 \mu \mathrm{g} \mathrm{Kg}^{-1}$ for eggs, with acceptable recoveries along with precision. The linearity was plotted in the range of 5-25 $\mu \mathrm{g} \mathrm{L}^{-1}$ (solvent) for egg and 10-50 $\mathrm{\mu g} \mathrm{Kg}^{-1}$ (matrix-matched) for muscles. The result of average recoveries showed the value of 70-94\% (3.3-12\% relative standard deviation (RSD)) for chicken muscles and $88-107 \%$ (2.5-18.6\% RSD) for egg samples, which meets the criteria for acceptability of method according to both SANTE and 2002/657/EC guidelines. This proposed protocol provides a cost-effective solution for food testing labs by reducing the cost of the sample preparation by $60 \%$ along with the time required for SPE cleanup. Further, the optimized method was also tested on real samples collected from nearby provinces in Solan city, Himachal Pradesh, India, and three out of 20 muscles were found to have colistin B in the range of $50-560 \mu \mathrm{g} \mathrm{Kg}^{-1}$.
\end{abstract}

Keywords: chicken; colistin; ultra-high-performance liquid chromatography; mass spectrometry 


\section{Introduction}

Colistin (polymyxin E) is a cationic peptide non-ribosomal antibiotic synthesized by Bacillus polymyxa subspecies colistinus, and is an active member of the polymyxin group [1,2]. Colistin is stated to be composed of approximately thirty different constituents. Out of all the components, colistin A (polymyxin E1) and colistin B (polymyxin E2) are the most predominant, accounting for $\geq 85 \%$ of colistin utilized in pharmaceutical products, which only differ because of the single carbon in the fatty acyl moiety [2]. Owing to high toxicity, this peptide antibiotic has been banned for human consumption, but still it is extensively used as a feed additive and veterinary drug in animal husbandry [3]. Worldwide, national health authorities have determined and established maximum residue limits (MRLs) for colistin in chicken muscles and eggs (Table 1).

Table 1. Maximum residue limits (MRLs) of colistin recommended by different regulatory agencies, adapted from Kumar et al. [1].

\begin{tabular}{ccc}
\hline Target Tissue & MRLs $\left(\boldsymbol{\mu g ~ K g} \mathbf{~}^{-\mathbf{1}}\right)$ & Regulatory Agency \\
\hline Muscle, Egg & 150,300 & EU \\
\hline Muscle, Egg & 150,300 & FSSAI \\
\hline Muscle & 150 & MAC \\
\hline Muscle & 150 & PHR Hong Kong \\
\hline $\begin{array}{l}\text { EU—European Union; FSSAI-Food Safety and Standards Authority of India; MAC—-Ministry of Agriculture } \\
\text { China; PHR Hong Kong—Public Health (Animals and Birds) (Chemical Residues) Regulation Hong Kong. }\end{array}$
\end{tabular}

In 2015, a team of researchers from China identified the colistin-resistant bacterial strain and stated that the presence of the mcr-1 gene was responsible for the development of colistin resistance in bacteria as it gets transferred from one bacterial strain to another [4]. Considering the analysis and reports related to this, the Chinese government in 2016 banned the usage of colistin for livestock. This led to a huge loss to pharmaceutical industries producing colistin, as China alone was responsible for the demand of 8000 tons of colistin per year, while the global demand was 12,000 tons per year. In spite of the ban, Chinese agrichemical companies are the leading manufacturer and exporter of colistin in countries like Vietnam, India and South Korea [5].

In India, five pharmaceutical companies producing animal drugs promote products containing colistin for metaphylactic purposes, as well as for growth. According to an investigation conducted by the Bureau of Investigative Journalism of London, chickens of India showed the presence of heavy residues of antibiotics in their tissues. In India, Venky's is the main seller of chicken products, and has reported the use of colistin in the livestock sector for therapeutic purposes [6]. These unregulated and non-monitored practices have led to the development of drug resistance in bacteria, and as per consensus, around $57 \%$ of bacteria (Gram-negative) in India alone are resistant to carbapenem. The Indian government has taken an initiative to prohibit colistin usage as a growth-enhancing supplement, but this initiative has failed to generate effective results due to a lack of association of government regulatory bodies in this initiative. Lately, the Food Safety and Standards Authority of India (FSSAI) has proposed to determine the antibiotics level (tolerance) in food products, and keeping this in focus in 2011, the standards governing contaminants, residues and toxins were revised [7]. In 2019, FSSAI put continuous effort into completely banning the use of colistin [8].

Even though colistin use is banned, there is still a need to monitor the colistin residue in animal origin foods. In preceding years, different liquid chromatography-tandem mass spectrometry (LC-MS/MS)-based methods were developed and used for investigating polypeptide antibiotics in animal origin food. For instance, Sin et al. [9] have reported the bacitracin A as well as the colistin $\mathrm{A}\left(50 \mu \mathrm{g} \mathrm{Kg}^{-1}\right)$ detection methods in bovine samples. Wan et al. [10] reported the use of an acidified extraction procedure for pretreatment of animal tissue and milk samples prior to solid-phase extraction using Strata-Xcartridge for 
detection of colistin B in samples. Similarly, Xu et al. [11] and Boison et al. [12] published methods for detecting the presence of colistin A (40 $\mathrm{g} \mathrm{Kg}^{-1}$ in fish and $39.0 \mu \mathrm{g} \mathrm{Kg}^{-1}$ chicken muscle) and B in fishery products and chicken muscle, respectively.

The aim of the present study was to develop a simple, cost effective and sensitive ultrahigh-performance liquid chromatography-tandem mass spectrometry (UHPLC-MS/MS) method and validate it for colistin B residue determination in chicken muscle as well as egg samples in contrast to the earlier reported methods, which involve acidic extraction followed by solid-phase extraction clean-up procedures. Further, the validation of this newly optimized method was done as per the SANTE and the Commission Decision 2002/657/EC guidelines.

\section{Materials and Methods}

\subsection{Chemicals, Reagents and Apparatus}

LC-MS grade methanol and formic acid ( $98 \%$ purity) were procured from Fisher Chemicals (Hampton, NH, USA). Deionized water (18.2 M $\Omega$ ) was obtained from the Bamstead ${ }^{\mathrm{TM}}$ MicroPure water purification system (ThermoScientific ${ }^{\mathrm{TM}}$ ). Syringe filters, labeled, CHROMAFIL Xtra polyethersulfone(PES), $25 \mathrm{~mm}, 0.20 \mu \mathrm{m}$, polytetrafluoroethylene(PTFE), $25 \mathrm{~mm}, 0.45 \mu \mathrm{m}$ and nylon, $25 \mathrm{~mm}, 0.45 \mu \mathrm{m}$ were purchased from MachereyNagel (Düren, Germany).

The reference standards of colistin sulfate (colistin was $753 \mu \mathrm{g} \mathrm{mg}^{-1}$, and colistin B was $53.6 \%$, according to the certificate of analysis) were procured from Sigma-Aldrich, Bangalore, India. The stock solution $\left(1000 \mu \mathrm{g} \mathrm{mL}^{-1}\right)$ of analyte was prepared in methanol/1\% formic acid in water $(1 / 1, v / v)$ by correcting the sulfate mass, and kept at $-20{ }^{\circ} \mathrm{C}$. The working standards were prepared via serial dilution with methanol $/ 1 \%$ formic acid in water $(1 / 1, v / v)$. These working standard solutions were then used for preparing linearity and spiking studies.

A refrigerated centrifuge Sorvall ${ }^{\mathrm{TM}}$ ST8 ventilated benchtop (ThermoScientific, San Jose, CA, USA), analytical balance (Aczet, CY2202) and precision balance (Aczet, CY205C, San Diego, CA, USA), vortex mixer (Thermo Scientific, USA), 2, 15 and $50 \mathrm{~mL}$ extraction/conical centrifuge tubes (Thermo Scientific) and Thermo Scientific variable volume Finnpipette $(100-1000 \mu \mathrm{L} ; 10-100 \mu \mathrm{L}$; and 0.5 to $5 \mathrm{~mL})$ were also used.

\subsection{LC-MS/MS Analysis}

An ultra-high-performance liquid chromatography (UHPLC Binary Flex) system coupled with a triple quadrupole mass spectrometer (TSQ Quantis, Thermo Scientific, San Jose, CA, USA) was used for colistin B analysis. To achieve the best sensitivity with symmetrical peak shapes of colistin B, reverse-phase column chemistry, i.e., Hypersil GOLD $^{\mathrm{TM}} \mathrm{C}_{18}(100 \times 2.1 \mathrm{~mm}, 1.9 \mu \mathrm{m})$ from Thermo Scientific, San Jose, USA, was used. The column oven and sample manager were maintained at $40{ }^{\circ} \mathrm{C}$ and $8{ }^{\circ} \mathrm{C}$, and the injection volume was $10 \mu \mathrm{L}$. The mobile phases comprised (A) $1 \%$ formic acid in water and (B) $1 \%$ formic acid in acetonitrile with a flow rate of $0.4 \mathrm{~mL} / \mathrm{min}$. Mobile phase gradient program includes $0-0.5 \mathrm{~min}, 5 \% \mathrm{~B} ; 0.5-3 \mathrm{~min}, 5-50 \% \mathrm{~B} ; 3-4 \mathrm{~min}, 50-80 \% \mathrm{~B} ; 4-5.8 \mathrm{~min}$, $80 \% \mathrm{~B}, 5.8-6 \mathrm{~min}, 80-5 \% \mathrm{~B} ; 6-9 \mathrm{~min}$, and $5 \% \mathrm{~B}$ phase.

The mass spectrometer was operated with new generation heated electrospray ionization (HESI) in positive mode $\left(\mathrm{ESI}^{+}\right)$. A selective reaction monitoring (SRM) mode was preferred for the analysis of colistin B [13]. The optimized compound-specific selective reaction monitoring transitions with radio frequency (RF) lens voltage and collision energies were determined. The operating ESI parameters (compound independent) included vaporizer temperature $\left(350^{\circ} \mathrm{C}\right)$, ion transfer tube temperature $\left(320^{\circ} \mathrm{C}\right)$, sheath gas $(50 \mathrm{Arb})$, aux gas (10 Arb), sweep gas (1 Arb), spray voltage $(3.5 \mathrm{kV})$. Data acquisition was performed using the SRM function, followed by data processing using TraceFinder $4.1 \mathrm{v}$ software (Thermo Scientific, San Jose, CA, USA). For identification and confirmation of the analyte, the SANTE guidelines (2019) were used [14]. 


\subsection{Sample Preparation}

Test samples were collected from known sources where colistin drug was not applied. The test samples were homogenized by using a mixer and grinder to ensure a small and uniform particle size. A test portion of $3 \pm 0.01 \mathrm{~g}$ (from homogenized chicken muscle and egg) was weighed in a $50 \mathrm{~mL}$ polypropylene centrifuged tube. Then $9 \mathrm{~mL}$ of methanol and $9 \mathrm{~mL} 1 \%$ formic acid in water were added to the centrifuged tube; the sample was vigorously shaken and vortexed for about $2 \mathrm{~min}$. This was followed by centrifugation for $10 \mathrm{~min}$ at $8500 \mathrm{rpm}$, and then the $1 \mathrm{~mL}$ of supernatant obtained was centrifuged for $10 \mathrm{~min}$ at $13,000 \mathrm{rpm}$ and filtered via a $0.20 \mu \mathrm{m}$ PES syringe filter into a vial (LC) for further analysis.

\subsection{Method Validation}

The performance of this method was evaluated in terms of specificity, linearity, recovery, precision and limit of quantitation (LOQ) [14,15]. To determine the specificity, blank samples $(n=20)$ of each matrix were examined and evaluated for intrusions near the colistin B retention times. The linearity was assessed by plotting five levels of calibration curves prepared in pure solvent and matrix. The matrix effect was evaluated by comparing the response of analyte in solvent as well as in a matrix. The accuracy was evaluated by recovery experiments at three different levels and the precision, stated as relative standard deviation (RSD), was ascertained by $n=6$ replicates. The LOQ was defined as the lowest concentrations with a signal-to-noise $(\mathrm{S} / \mathrm{N})$ ratio of 10:1, and also validated to obtain acceptable recovery (70-120\%) with less than $20 \%$ RSD.

\section{Results and Discussion}

\subsection{LC-MS/MS Analysis}

In this work, the mass parameters were optimized with the help of infusing $1 \mu \mathrm{g} \mathrm{mL}^{-1}$ standard solution of colistin prepared in methanol $/ 1 \%$ formic acid in water. Data were acquired in a full scan with electrospray ionization (ESI) with positive polarity. The most abundant parent ions were observed with doubly charged ion $578.1[\mathrm{M}+2 \mathrm{H}]^{2+}$ and triply charged ion $386.1[\mathrm{M}+3 \mathrm{H}]^{3+}$. Furthermore, the RF lens voltage was optimized to achieve the best performance of both ions. The most abundant ion $\mathrm{m} / \mathrm{z} 386.1[\mathrm{M}+3 \mathrm{H}]^{3+}$ was selected as the precursor ion for further optimization. The parent ion was further fragmented by applying collision energy (argon gas). The full MS and MS/MS spectra for the colistin are represented in Figure 1A-C. The best sensitive and stable fragment/product ions were selected for selective reaction monitoring mode in agreement with earlier reported articles $[10,16]$. Details of the compound-dependent optimized parameters are listed in Table 2.

Compound-independent (ion source) parameters optimized based on the mobile phase composition showed the best sensitivity at $1 \mathrm{ng} \mathrm{mL}^{-1}$ (instrument quantitation limit).

As colistin is a polar analyte, reverse phase chromatography is preferred in agreement with $\mathrm{Fu}$ et al. [16]. The terminal amino group enables more interaction with the $\mathrm{C}_{18}$ column chemistry followed by peak tailing. To avoid this, the addition of formic acid was preferred along with acetonitrile solvent, which offered the best ionization efficiency [16]. The gradient program was optimized in such a way that all the polar interference was eluted earlier than the target analyte, and there was no positive signal observed at the observed retention time (3.17). The runtime was extended to $9 \mathrm{~min}$ to ensure that the entire matrix interferences coming along with target analytes were completely eluted, and did not have any adverse effect on the next injection (sample/standard). These conditions were able to reduce the matrix effect in both the matrices. In the present study, an acidified mobile phase offered optimum retention, symmetrical peak shape and reproducible signal with retention time (Figure 2) in comparison with Fu et al. [16]. 


\subsection{Sample Preparation}

By considering the complexity of matrices as well as the physicochemical properties of colistin, a method for sample preparation was developed. It was further modified after studying the core literature using LC-MS/MS for polypeptide antibiotics determination in animal origin food. The published literature for sample preparation primarily discusses the deproteinization step (referred to as acidic pretreatment), performed with the help of organic solvents (acetonitrile and methanol) and acids (trichloroacetic acid and hydrochloric acid) in varied combinations, as shown in Table $3[2,9-12,16,17]$.
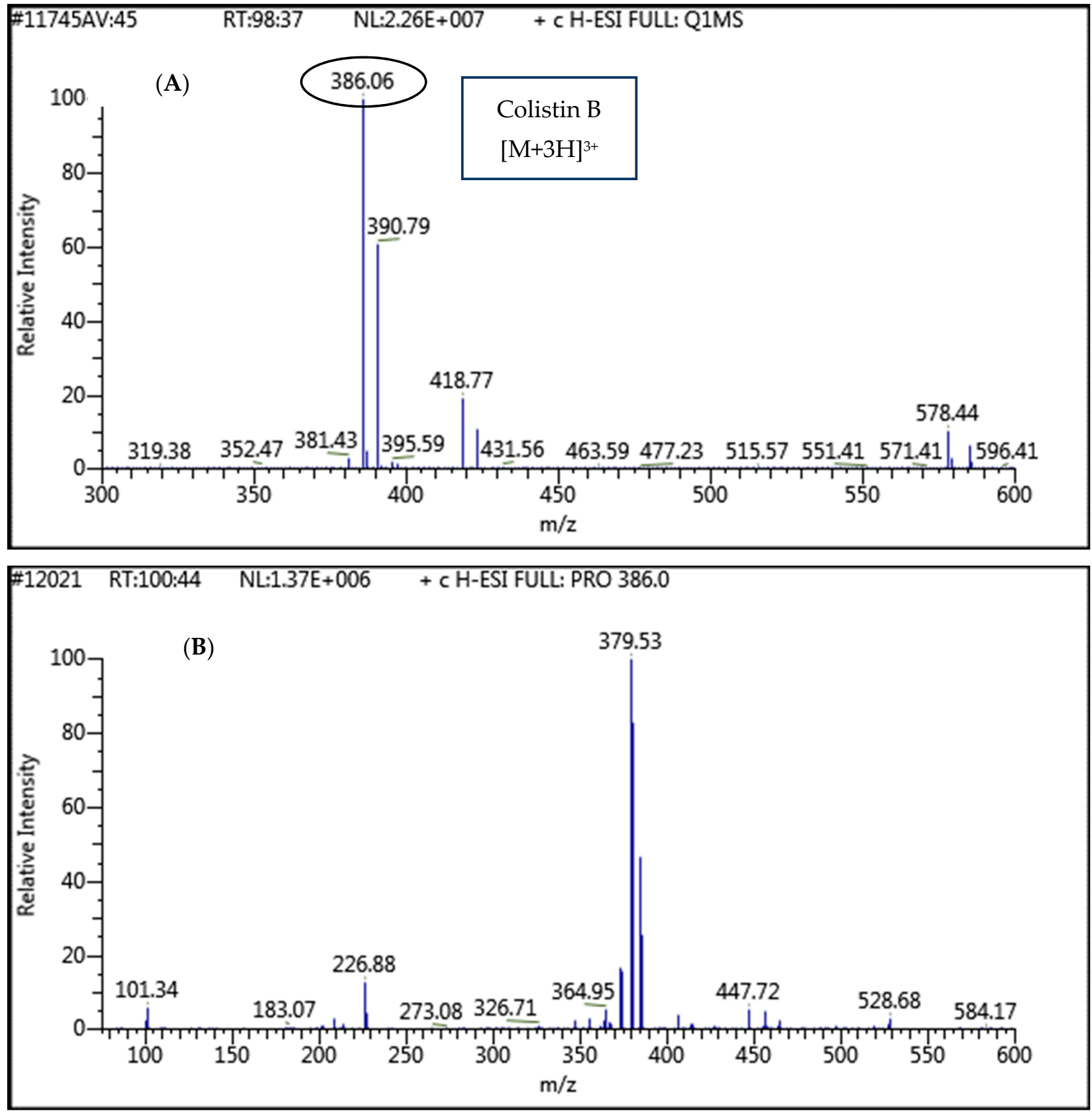

Figure 1. Cont. 


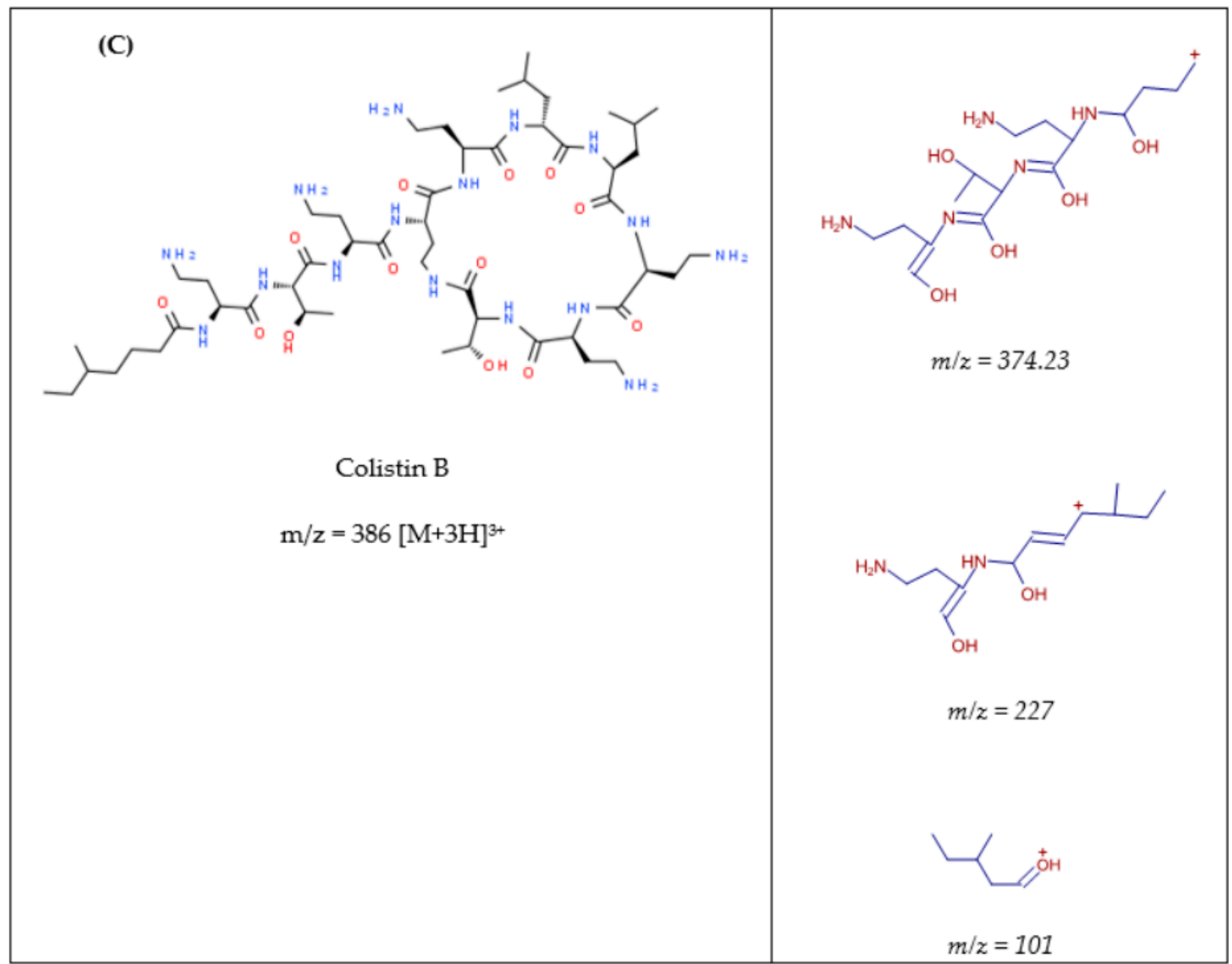

Figure 1. The full MS (A) and MS/MS spectra (B), and fragmented structures (C) for colistin B.

Table 2. Ultra-high-performance liquid chromatography-tandem mass spectrometry (UHPLC-MS/MS) parameters for colistin B and its validation results in chicken muscle and egg.

\begin{tabular}{|c|c|c|c|c|c|c|c|c|c|c|}
\hline Adduct & $\begin{array}{l}\text { Precursor } \\
\text { ion }(m / z)\end{array}$ & $\begin{array}{c}\text { Product } \\
\text { ions }(\mathrm{m} / \mathrm{z})\end{array}$ & $\begin{array}{l}\text { RF Lens } \\
\text { (V) }\end{array}$ & $\mathrm{CE}(\mathrm{eV})$ & $\begin{array}{c}\text { Calibration } \\
\text { Range }\end{array}$ & Linearity & LOQ $\left(\mu \mathrm{g} \mathrm{Kg}^{-1}\right)$ & \multicolumn{3}{|c|}{ \% Recovery (RSD \%) } \\
\hline \multicolumn{8}{|c|}{ Muscle } & $10 \mu \mathrm{g} \mathrm{Kg}^{-1}$ & $50 \mu \mathrm{g} \mathrm{Kg}^{-1}$ & $100 \mu \mathrm{g} \mathrm{Kg}^{-1}$ \\
\hline$[\mathrm{M}+3 \mathrm{H}]^{3+}$ & 386.1 & 374.3 & \multirow{4}{*}{122} & 12.12 & \multirow{4}{*}{$1-50 \mathrm{ng} \mathrm{mL}^{-1}$} & \multirow{4}{*}{0.998} & \multirow{4}{*}{10} & \multirow{4}{*}{$71.1(12.1)$} & \multirow{4}{*}{70.7 (6.6) } & \multirow{4}{*}{$93.8(3.3)$} \\
\hline$[\mathrm{M}+3 \mathrm{H}]^{3+}$ & 386.1 & 380.1 & & 10.52 & & & & & & \\
\hline$[\mathrm{M}+3 \mathrm{H}]^{3+}$ & 386.1 & 227.1 & & 15.83 & & & & & & \\
\hline$[\mathrm{M}+3 \mathrm{H}]^{3+}$ & 386.1 & 101.1 & & 15.98 & & & & & & \\
\hline \multicolumn{8}{|c|}{ Egg } & $5 \mu \mathrm{g} \mathrm{Kg}^{-1}$ & $10 \mu \mathrm{g} \mathrm{Kg}^{-1}$ & $150 \mu \mathrm{g} \mathrm{Kg}^{-1}$ \\
\hline$[\mathrm{M}+3 \mathrm{H}]^{3+}$ & 386.1 & 374.3 & \multirow{4}{*}{122} & 12.12 & \multirow{4}{*}{$1-25 \mathrm{ng} \mathrm{mL}^{-1}$} & \multirow{4}{*}{0.994} & \multirow{4}{*}{5} & \multirow{4}{*}{$88.6(18.6)$} & \multirow{4}{*}{$107.5(11.5)$} & \multirow{4}{*}{$105.5(2.5)$} \\
\hline$[\mathrm{M}+3 \mathrm{H}]^{3+}$ & 386.1 & 380.1 & & 10.52 & & & & & & \\
\hline$[\mathrm{M}+3 \mathrm{H}]^{3+}$ & 386.1 & 227.1 & & 15.83 & & & & & & \\
\hline$[\mathrm{M}+3 \mathrm{H}]^{3+}$ & 386.1 & 101.1 & & 15.98 & & & & & & \\
\hline
\end{tabular}

CE—collision energy; RF—radio frequency; LOQ—-limit of quantitation; RSD—relative standard deviation.

The developed method is a rapid, simple extraction, which allows users to determine colistin B antibiotic residue in chicken samples at quite low concentration levels. Colistin is a cationic peptide antibiotic with weak acid (carboxylic acid) and base (amino) functional groups. Bladek et al. [2] have reported that colistin could be found in three formsdeprotonated base form, neutral form or protonated acid form. Colistin is highly polar in nature, hence why in the present study polar extraction solvents i.e., methanol and acidified water, were used [18]. In the present approach, the solid-phase extraction (SPE) 
step was omitted due to tedious processes, long handling time and chances of losing the analyte during sample loading, washing and elution. As methanol and water have good miscibility, there is no phase separation which provides good solubility for colistin. The addition of acidified water is essential to maintain the water level which helps in the matrix dilution. The mixing of methanol and water generated heat due to exothermic reactions and induced better solubility and extractability of the target analyte with less fat interference in comparison with acetonitrile. Acetonitrile carries more fatty content which may interfere with the analysis, followed by disturbance in the column. Without SPE cleanup, the direct injection of methanolic extract was possible due to less fatty matrix co-elution in the proposed protocol. These extraction conditions offered better stability in acidic conditions in both the matrices. The final extract was filtered via a PES membrane filter, which provided a clear and transparent extract by reducing turbidity as compared to other membrane filters (nylon and PTFE). These optimized extraction conditions offered acceptable recovery $(70-120 \%)$ and precision $(<20 \%)$. This protocol was also compared with the method of Bladek et al. [2] which used acetonitrile/ammoniabased extraction. There was no significant difference observed in terms of performance (recovery and precision) of the method. The acetonitrile/ammonia-based extraction carried a high matrix background which reduced the $\mathrm{S} / \mathrm{N}$ ratio for the target analyte by $30-40 \%$ as compared to the proposed method. In comparison with previously published reports (Table 3), the proposed method has demonstrated the highest sensitivity of $5 \mathrm{\mu g} \mathrm{Kg}^{-1}$ for eggs and $10 \mu \mathrm{g} \mathrm{Kg}^{-1}$ for chicken muscles.

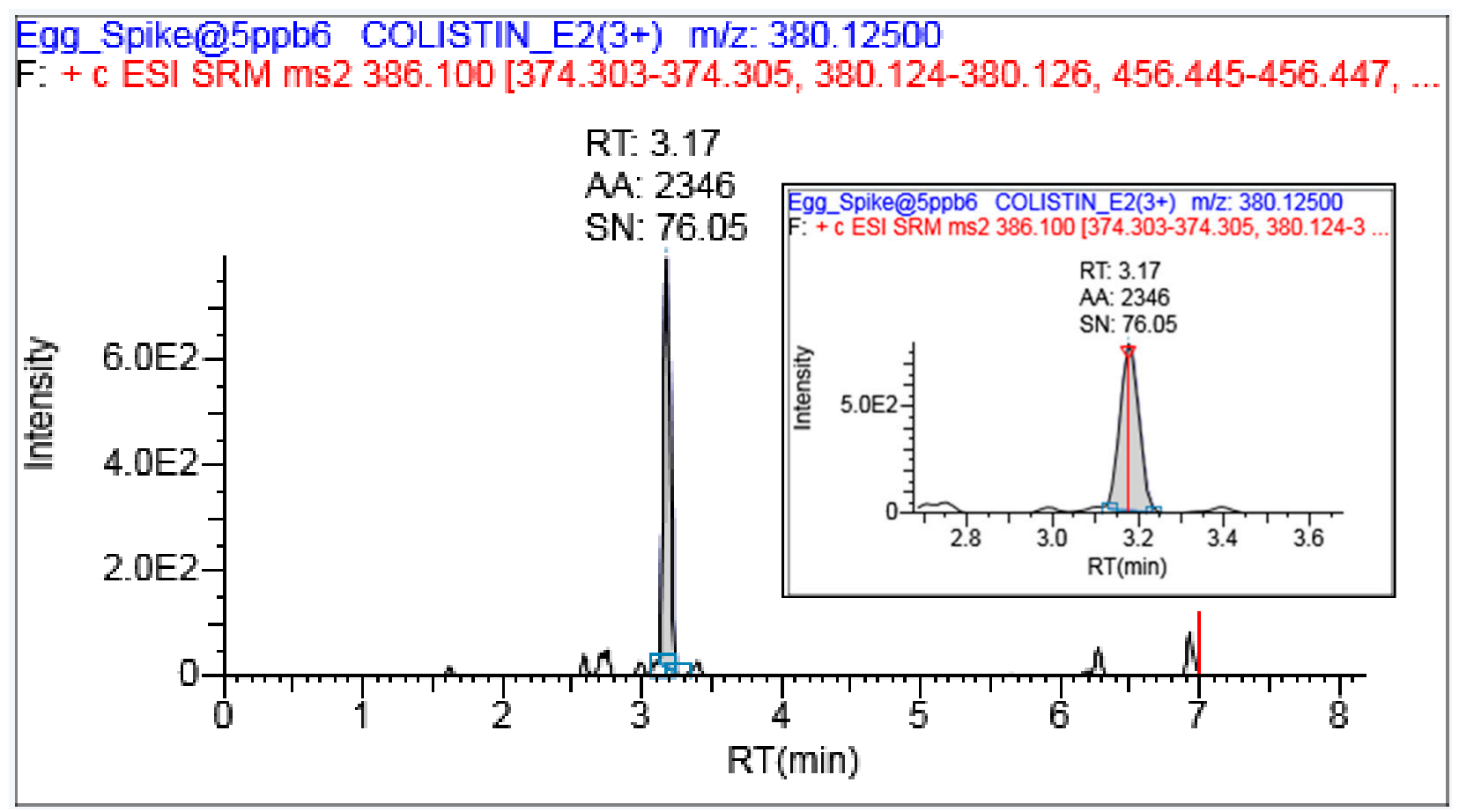

Figure 2. Representative chromatogram for colistin B under the optimized acidified mobile phase. RT: Retantion time; AA: Absolute Area; SN: Single to Nosie Ratio

\subsection{Method Validation}

\subsubsection{Linearity}

In this method, the linearity was plotted in the range of $1-25 \mu \mathrm{g} \mathrm{L}{ }^{-1}$ in pure solvent for egg matrix and $1-50 \mu \mathrm{g} \mathrm{Kg}^{-1}$ in chicken muscle matrix (Figure 3). A high linearity was achieved in both the solvent as well as the matrix, with correlation coefficients $\geq 0.99$ and lower than $\pm 20 \%$ residuals using a linear equation and $1 / x$ weighting factor, as illustrated in Table 2. 
Table 3. Comparison of earlier reported sample preparation protocols used for colistin B detection with newly proposed protocol.

\begin{tabular}{|c|c|c|c|c|c|c|}
\hline Sample Type & Sample Weight (g) & Extraction & Clean Up & Evaporation Used & LOQ $\left(\mu \mathrm{g} \mathrm{Kg}^{-1}\right)$ & References \\
\hline Muscle, Egg & 2 & $\begin{array}{l}\text { Acetonitrile, } \\
\text { Water and } \\
\text { Ammonia }\end{array}$ & NA & Nitrogen & 10 & [2] \\
\hline $\begin{array}{l}\text { Bovine Liver, } \\
\text { Kidney }\end{array}$ & 0.5 & $\begin{array}{l}\text { Trichloroacetic } \\
\text { Acid, Acetonitrile, } \\
\text { and Formic Acid }\end{array}$ & $\begin{array}{l}\text { OASIS }^{\circledR} \text { HLB } \\
\text { Sep-pak }\end{array}$ & Nitrogen & 50 & [9] \\
\hline $\begin{array}{c}\text { Bovine Muscle, } \\
\text { Liver }\end{array}$ & 2.5 & $\begin{array}{l}\text { Hydrochloric } \\
\text { Acid }\end{array}$ & $\begin{array}{l}\text { Phenomenex } \\
\text { Strata- } X \\
\text { cartridges }\end{array}$ & Nitrogen & 2/5 (MRL) & [10] \\
\hline Fishes & 5 & $\begin{array}{c}\text { Methanol, Water, } \\
\text { and Hydrochloric } \\
\text { Acid }\end{array}$ & ProElut PLS & Nitrogen & 40 & [11] \\
\hline Chicken Muscle & 5 & $\begin{array}{c}\text { Trichloroacetic } \\
\text { Acid, Methanol, } \\
\text { Water and } \\
\text { Hydrochloric } \\
\text { Acid }\end{array}$ & IRIS Polymeric & Nitrogen & 50 & [12] \\
\hline $\begin{array}{l}\text { Porcine Muscle, } \\
\text { Liver, Kidney; } \\
\text { Bovine Muscle, } \\
\text { Liver, Kidney; } \\
\text { Chicken Muscle, } \\
\text { Liver, Kidney, } \\
\text { Egg; Sheep } \\
\text { Muscle }\end{array}$ & 2 & $\begin{array}{l}\text { Trichloroacetic } \\
\text { Acid, and } \\
\text { Acetonitrile }\end{array}$ & Oasis WCX & Nitrogen & $5-30$ & [16] \\
\hline Bovine Muscle & 3 & $\begin{array}{c}\text { Ammonium } \\
\text { Acetate, EDTA, } \\
\text { Trichloroacetic } \\
\text { Acid and Sodium } \\
\text { Chloride }\end{array}$ & Sep-PAK WCX & NA & 33 & [17] \\
\hline $\begin{array}{c}\text { Chicken Muscle, } \\
\text { Egg }\end{array}$ & 3 & $\begin{array}{l}\text { Methanol, Water } \\
\text { and Formic Acid }\end{array}$ & NA & NA & 10 and 5 & $\begin{array}{l}\text { Present } \\
\text { Study }\end{array}$ \\
\hline
\end{tabular}

NA-not applicable.

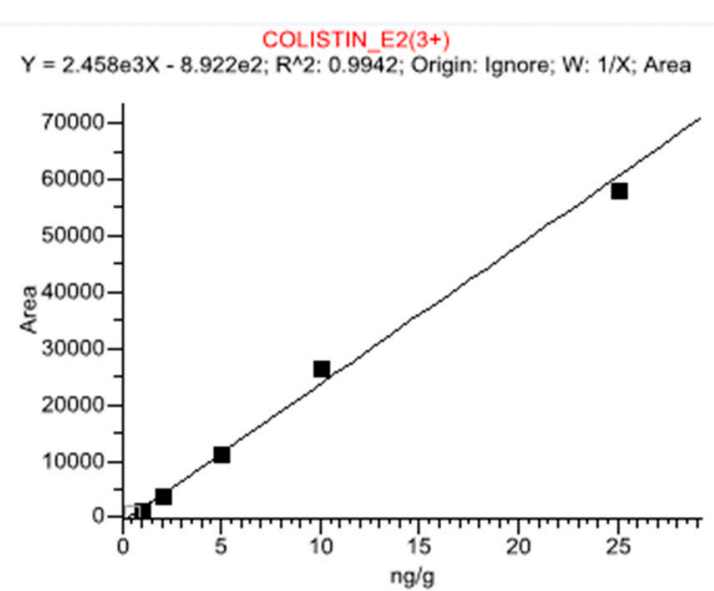

(A)

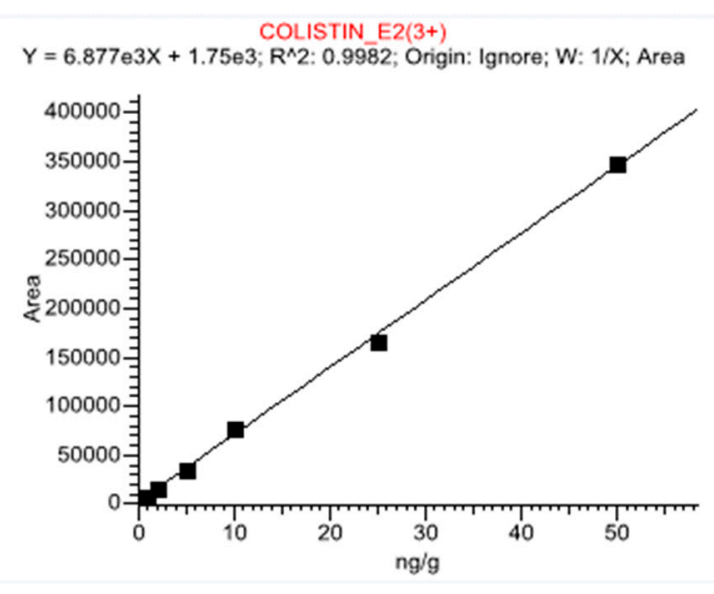

(B)

Figure 3. Linearity plot of pure solvent standard used for egg matrix (A), and in chicken muscle matrix (B).

\subsubsection{Limit of Quantitation (LOQ)}

The LOQ value was set at $5 \mu \mathrm{g} \mathrm{Kg}^{-1}$ and $10 \mu \mathrm{g} \mathrm{Kg}^{-1}$ in egg and chicken muscle, respectively (Table 2), which offered acceptable recoveries within $70-120 \%$ with $<20 \%$ RSD for six replicates in both the matrices. The comparison of LOQs observed in the proposed method and earlier reported methods are represented in Table 3. The extracted 
ion chromatograms (EICs) of colistin B for both matrices at the LOQ level spike and blank matrix are shown in Figure 4. The observed LOQ values were well below the established MRLs, given in Table 1, which help to monitor colistin at a trace level, as it is banned [1].
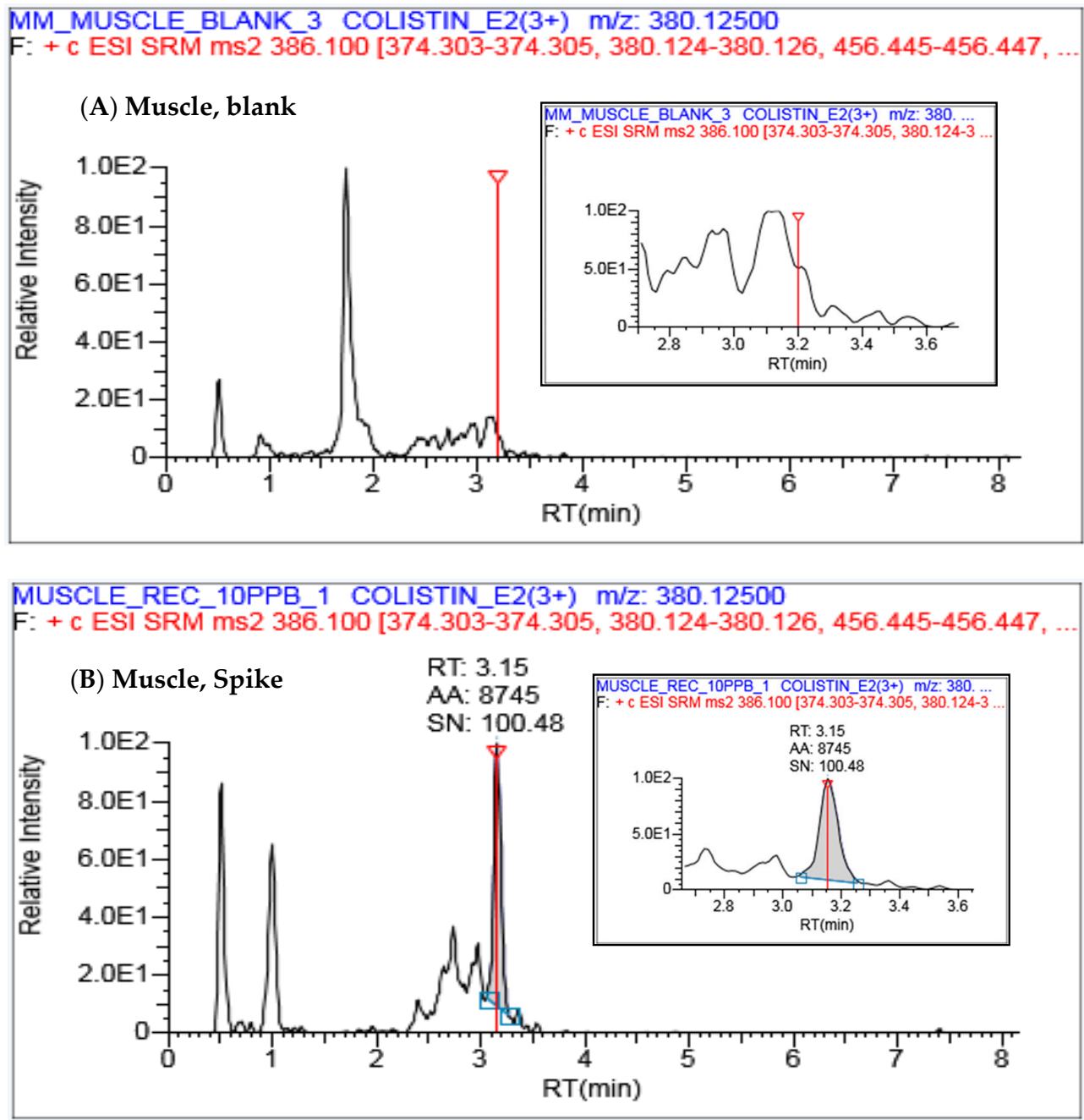

Egg_Blank COLISTIN_E2(3+) $\mathrm{m} / \mathrm{z}: 380.12500$

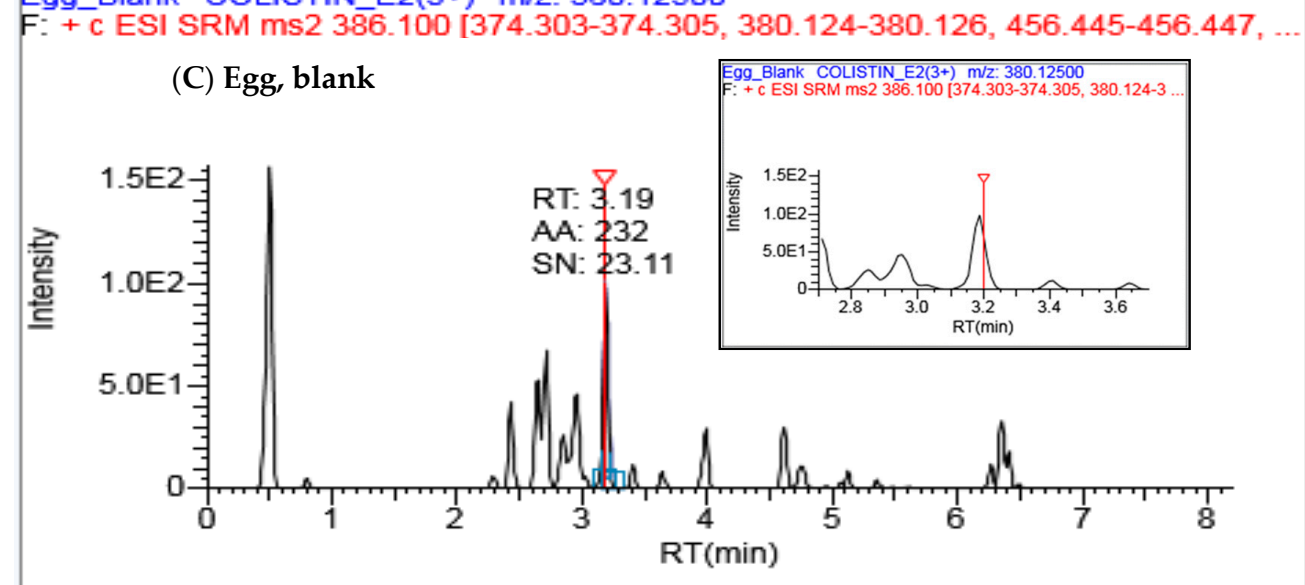

Figure 4. Cont. 


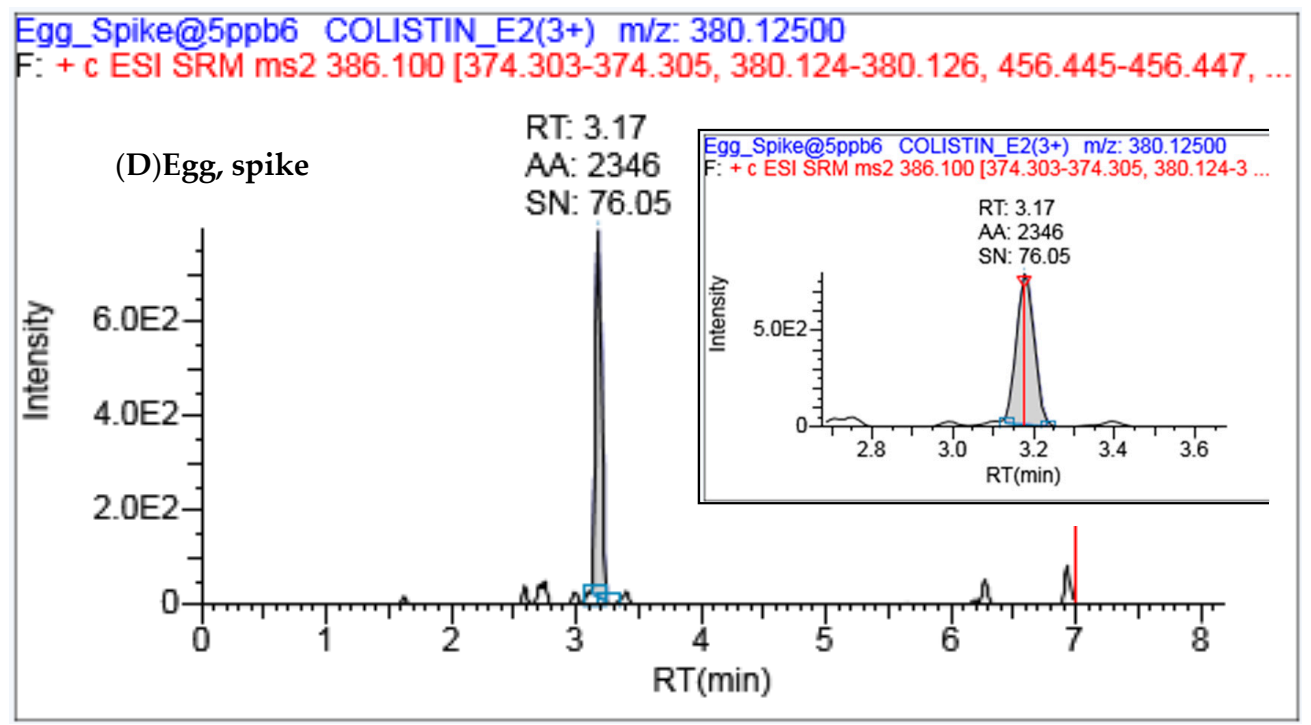

Figure 4. Extracted ion chromatogram (EIC) of colistin B in (A) chicken muscle blank, (B) $10 \mu \mathrm{g} \mathrm{Kg}^{-1}$ spiked muscle, (C) egg blank and (D) $5 \mu \mathrm{g} \mathrm{Kg}{ }^{-1}$ spiked egg.

\subsubsection{Matrix Effect}

The matrix effect observed in eggs was within $< \pm 15-20 \%$, and was considered as a low matrix effect within the acceptance criteria of the SANTE guideline, and colistin B quantification was performed using external standard calibration $\left(1-25 \mu \mathrm{g} \mathrm{Kg}^{-1}\right)$ prepared in pure solvent. In the case of the chicken muscle, the matrix effect was observed in the range of $40-55 \%$. To harmonize the results in the muscle, matrix match calibration was preferred in the range of $1-50 \mu \mathrm{g} \mathrm{Kg}^{-1}$. The quantitation of colistin B was successfully demonstrated in both the matrices using this approach.

\subsubsection{Recovery and Precision}

The recovery experiment was conducted by use of reference material (RM) to demonstrate the accuracy of this method. In this study, the recovery is assessed through the measurements of additions of known amounts of the analyte at three different levels to a blank matrix, with six replicates for each level. The chromatograms with the lowest spiking level in both the matrices are shown in Figure 4. The average recoveries were observed within $70-94 \%$ (3.3-12\% RSD) in chicken muscles and 88-107\% (2.5-18.6\% RSD) in egg samples, which demonstrated the acceptability of the method as per the SANTE 2019 as well as Commission Decision 2002/657/EC guidelines, respectively [14,15].

\subsection{Analysis of Real Samples}

Using this method, detection of colistin B was done in real chicken muscles and eggs. Sampling was carried out for 50 samples (30 eggs and 20 muscles) based on a nonprobability approach in Solan, Himachal Pradesh, India. All the samples were extracted as per the stated protocol and analyzed using LC-MS/MS under the above optimized conditions. Out of 20 muscles, three samples had a colistin B concentration range of $50-560 \mu \mathrm{g} \mathrm{Kg}^{-1}$. However, the egg samples did not show the presence of colistin B in them.

\section{Conclusions}

This article represents a simple, robust, cost-effective and sensitive sample preparation protocol followed by LC-MS/MS analysis of colistin B in chicken muscles and eggs. The proposed method has been validated and established for its specificity, accuracy and suitability for routine and repetitive analysis in chicken products for regulating colistin utilization. The unregulated colistin usage in animal husbandry has prompted the evaluation of the presence of colistin sulfate residue in both tissues and chicken feed, so that an 
effective measure can be developed. Additionally, the monitoring of colistin sulfate in both tissues and chicken feed will enforce the regulated use of colistin (feed additives) during food animal production. Based on the present study, a highly economical and simple method for colistin B extraction is developed in difficult matrices like chicken muscles and eggs, without the use of SPE clean-up procedures. This proposed protocol provides a cost-effective solution for food testing labs by reducing $60 \%$ cost of the sample preparation along with the time required for SPE cleanup. The developed protocol can also increase the throughput of commercial food testing labs.

Author Contributions: Conceptualization, D.K. and K.K.; methodology, D.O.; software, R.M.R.A.; validation, H.K., S.K.B. and D.O.; formal analysis, D.O.; investigation, H.K.; resources, D.K. and K.K.; data curation, H.K.; writing—original draft preparation, H.K.; writing—review and editing, E.N., A.K., N.K.U. and R.V.; visualization, D.O., D.K.; supervision, D.K.; project administration, K.K.; funding acquisition, K.K. All authors have read and agreed to the published version of the manuscript.

Funding: This research was funded by the University of Hradec Kralove (VT2019-2021).

Institutional Review Board Statement: Not Applicable.

Informed Consent Statement: Not Applicable.

Acknowledgments: We acknowledge University of Hradec Kralove (VT2019-2021-KK, EN) for financial support.

Conflicts of Interest: The authors declare no conflict of interest.

\section{References}

1. Kumar, H.; Chen, B.H.; Kuca, K.; Nepovimova, E.; Kaushal, A.; Nagraik, R.; Bhatia, S.K.; Dhanjal, D.S.; Kumar, V.; Kumar, A.; et al. Understanding of colistin usage in food animals and available detection techniques: A review. Animals 2020, 10, 1892. [CrossRef] [PubMed]

2. Bladek, T.; Szymanek, B.I.; Posyniak, A. Determination of polypeptide antibiotic residues in food of animal origin by ultra-highperformance liquid chromatography-tandem mass spectrometry. Molecules 2020, 25, 3261. [CrossRef] [PubMed]

3. Catry, B.; Cavaleri, M.; Baptiste, K.; Grave, K.; Grein, K.; Holm, A.; Jukes, H.; Liebana, E.; Lopez Navas, A.; Mackay, D.; et al. Use of colistin-containing products within the European Union and European Economic Area (EU/EEA): Development of resistance in animals and possible impact on human and animal health. Int. J. Antimicrob. Agents 2015, 46, 297-306. [CrossRef] [PubMed]

4. Liu, Y.Y.; Wang, Y.; Walsh, T.R.; Yi, L.X.; Zhang, R.; Spencer, J.; Doi, Y.; Tian, G.; Dong, B.; Huang, X.; et al. Emergence of plasmid-mediated colistin resistance mechanism mcr-1 in animals and human beings in China: A microbiological and molecular biological study. Lancet Infect. Dis. 2016, 16, 161-168. [CrossRef]

5. Davies, M.; Walsh, T.R. A colistin crisis in India. Lancet Infect. Dis. 2018, 18, 256-257. [CrossRef]

6. Livemint. Govt May Ban Antibiotic Colistin Used to Fatten Chicken. Available online: https://www.livemint.com/Industry/yt5 eE5hqMLYP1px2d63Q1K/Govt-may-ban-antibiotic-colistin-used-to-fatten-chicken.html (accessed on 20 June 2019).

7. TOI. Tolerance Limits' to Be Fixed by Food Regulator for Presence of Antibiotics in Animal, Foods. Available online: https: //www.fssai.gov.in/upload/media/FSSAI_News_AntiBiotics_TOI_01_08_2018.pdf (accessed on 12 June 2019).

8. FSSAI. Direction under Section 16(5)Read with 18(2)(d)of Food Safety and Standard Act, 2006 Regarding Operationalisation of Draft Food Safety and Standard (Contaminants, Toxins and Residues) Amendment Regulations. 2019. Available online: https:/ / www.fssai.gov.in/upload/advisories /2019/08/5d4c042779d77Direction_Colistin_Ban_FSSAI_08_08_2019.pdf (accessed on 8 September 2019).

9. Sin, D.W.; Ho, C.; Wong, Y.C.; Ho, S.K.; Ip, A.C.B. Analysis of major components of residual bacitracin and colistin in food samples by liquid chromatography tandem mass spectrometry. Anal. Chim. Acta 2005, 535, 23-31. [CrossRef]

10. Wan, E.C.; Ho, C.; Sin, D.W.; Wong, Y.C. Detection of residual bacitracin A, colistin A, and colistin B in milk and animal tissues by liquid chromatography tandem mass spectrometry. Anal. Bioanal. Chem. 2006, 385, 181-188. [CrossRef] [PubMed]

11. Xu, I.; Tian, X.; Ren, C.; Huang, H.; Zhang, X.; Gong, X.; Liu, H.; Yu, Z.; Zhang, L. Analysis of colistin A and B in fishery products by ultra performance liquid chromatography with positive electro spray ionization tandem mass spectrometry. J. Chromatogr. $B$ 2012, 899, 14-20. [CrossRef] [PubMed]

12. Boison, J.O.; Lee, S.; Matus, J. A multi-residue method for the determination of seven polypeptide drug residues in chicken muscle tissues by LC-MS/MS. Anal. Bioanal. Chem. 2015, 406, 4065-4078. [CrossRef] [PubMed]

13. Pascale, R.; Bianco, G.; Coviello, D.; Lafiosca, M.C.; Masi, S.; Mancini, I.M.; Bufo, S.A.; Scrano, L.; Caniani, D. Validation of a LC-MS/MS method for the determination of drugs in wastewater using a three-phase solvent system. J. Sep. Sci. 2020, 43, 886-895. [CrossRef] [PubMed]

14. SANTE. Available online: https://ec.europa.eu/food/sites/food/files/plant/docs/pesticides_mrl_guidelines_wrkdoc_2019 -12682.pdf (accessed on 8 December 2020). 
15. European Communities. Commission Decision (2002/657/EC) of 12 August 2002 implementing Council Directive 96/23/EC concerning the performance of analytical methods and the interpretation of results. Off. J. Eur. Communities 2002, L221, 8-36.

16. Fu, Q.; Li, X.; Zheng, K.; Ke, Y.; Wang, Y.; Wang, L.; Yu, F.; Xia, X. Determination of colistin in animal tissues, egg, milk, and feed by ultra-high performance liquid chromatography-tandem mass spectrometry. Food Chem. 2018, 248, 166-172. [CrossRef] [PubMed]

17. Saluti, G.; Diamanti, I.; Giusepponi, D.; Pucciarini, L.; Rossi, R.; Moretti, S.; Sardella, R.; Galarini, R. Simultaneous determination of aminoglycosides and colistins in food. Food Chem. 2018, 266, 9-16. [CrossRef] [PubMed]

18. QuPPe-Method. Available online: https://www.eurl-pesticides.eu/userfiles/file/EurlSRM/meth_QuPPe_AO.pdf (accessed on 10 December 2020). 